\title{
Crystal Structure of a Rhodium(I) Complex with a Chelating Bidentate Isonitrile Ligand Containing Nitrogen Bridging Groups
}

\author{
Xuan Shen,* Yasushi YAMAguChI, $* *$ Kazunori SAKata, ${ }^{* * \dagger}$ and Mamoru HaShIMOTO ${ }^{* *}$ \\ *Department of Chemistry, Key Laboratory of Material-oriented Chemical Engineering of Jiangsu \\ Province, Nanjing University of Technology, 5 New Mofan Road, Nanjing 210009, China \\ **Department of Applied Chemistry, Faculty of Engineering, Kyushu Institute of Technology, \\ 1-1 Sensui-cho, Tobata-ku, Kitakyushu 804-8550, Japan
}

\begin{abstract}
A rhodium(I) complex with a chelating bidentate isonitrile ligand, 1,2-bis(4-tert-butyl-2isocyanophenylmethylamine)ethane $\left(\mathrm{Rh}[t-\mathrm{BuDinMeNC}]_{2} \mathrm{BF}_{4}\right)$, was synthesized and characterized by $\mathrm{X}$-ray crystallography. The complex crystallizes in a triclinic crystal system under the space group $P \overline{1}$ and $Z=2$ with $a=$ 10.3165(6) $\AA, b=15.5162(9) \AA, c=19.0534(11) \AA, \alpha=68.166(1)^{\circ}, \beta=78.973(1)^{\circ}, \gamma=89.329(1)^{\circ}, V=2773.0(3) \AA^{3}$. The complex is square-planar, and the $\mathrm{BF}_{4}^{-}$anion exists as a counter ion. This is the first structural example of a bidentate isonitrile-containing complex having a square-planar structure.
\end{abstract}

(Received September 18, 2004; Accepted March 5, 2005; Published on web May 19, 2005)

The syntheses and characterizations of bidentate isonitrile ligand-containing complexes were first summarized by Angelici et al. ${ }^{1}$ Ligands containing ethereal oxygen bridging groups ${ }^{2}$ and thioethereal sulfur bridging groups ${ }^{3}$ were also reported. Though these ligands contain four coordination sites, namely two oxygen atoms or two sulfur atoms in the bridging group and two carbon atoms in the isonitrile groups, metal ions are only coordinated through the carbon atoms of the isonitrile groups. However, the metal ions are coordinated to two carbons of the isonitrile to form a thirteen-membered ring structure, and the isonitrile can also act as a bidentate ligand to form a squareplanar complex. Herein, we report on our latest investigation of a bidentate isonitrile ligand containing amine bridging groups. 1,2-Bis(4-tert-butyl-2-isocyanophenylmethylamine)ethane $\quad(t$ $\mathrm{BuDinMeNC}$ ) was synthesized for the first time. A rhodium(I) complex with the ligand $\left(\mathrm{Rh}[t-\mathrm{BuDinMeNC}]_{2} \mathrm{BF}_{4}\right)$ was prepared and characterized by $\mathrm{X}$-ray crystallography.

$t$-BuDinMeNC was synthesized as shown in Scheme 1. It was fully characterized by elemental analysis, mass and infrared and ${ }^{1} \mathrm{H} \quad \mathrm{NMR} \quad$ spectroscopy. Bis(1,5-cyclooctadiene)dichlororhodium(I) (0.030 g, $0.0608 \mathrm{mmol})$ was dissolved in dichloromethane $(5 \mathrm{ml})$ under a nitrogen atmosphere. After this solution was stirred for $5 \mathrm{~min}$, a solution of $t$-BuDinMeNC $(0.098 \mathrm{~g}, 0.243 \mathrm{mmol})$ in dichloromethane (6 $\mathrm{ml}$ ) was added. The reaction solution was stirred at room

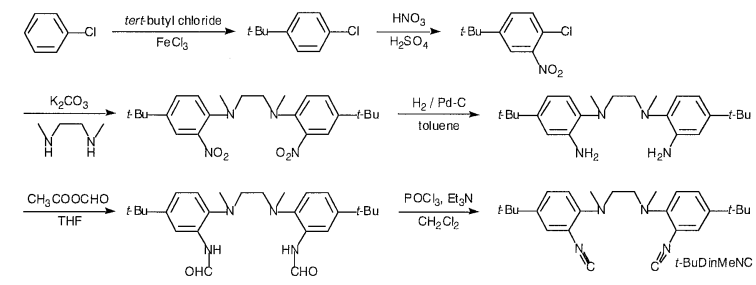

Scheme 1 Synthesis of $t$-BuDinMeNC

To whom correspondence should be addressed. temperature for $5 \mathrm{~h}$, and was then filtrated. The volume of the filter liquor was reduced to half by evaporation. When the product precipitated from the solution after hexane was added, the solution was kept at $5^{\circ} \mathrm{C}$ for $12 \mathrm{~h}$. A green-yellow powder of complex $\mathrm{Rh}[t-\mathrm{BuDinMeNC}]_{2} \mathrm{Cl}$ was obtained by filtration, and was fully washed with diethyl ether. The title complex, $\mathrm{Rh}[t \text {-BuDinMeNC}]_{2} \mathrm{BF}_{4}$, was gained by the anion-exchange reaction of $\mathrm{Rh}[t-\mathrm{BuDinMeNC}]_{2} \mathrm{Cl}$ and $\mathrm{NaBF}_{4}$ in dichloromethane. Red crystals of $\mathrm{Rh}[t-\mathrm{BuDinMeNC}]_{2} \mathrm{BF}_{4}$ (Fig. 1) containing one molecule of hexane (used in the synthetic process) and one molecule of ethanol, which were suitable for X-ray crystal structure analysis, were obtained by recrystallization from hexane and ethanol ( $\mathrm{vol} / \mathrm{vol}, 1: 1)$ in a yield of 38\%. Anal. Found: H, 7.46; C, 63.38; N, 10.27. Calc. for $\mathrm{C}_{57} \mathrm{H}_{81} \mathrm{BF}_{4} \mathrm{~N}_{8} \mathrm{ORh}: \mathrm{H}, 7.53 ; \mathrm{C}, 63.16 ; \mathrm{N}, 10.34 \%$.

All non-hydrogen atoms were refined with anisotropic thermal parameters. Most of the hydrogen atoms were located at calculated positions and/or at positions found from difference Fourier maps. Crystal data and details associated with data collection are summarized in Table 1. Figure 2 shows an ORTEP view of the title complex without a solvent. Selected bond lengths and angles are listed in Table 2. In the complex, the $\mathrm{Rh}(\mathrm{I})$ atom is coordinated with four carbon atoms of two isonitrile ligands to form a square-planar complex cation, while it is not coordinated with two nitrogen atoms of the amine bridging group in the isonitrile to form a thirteen-membered

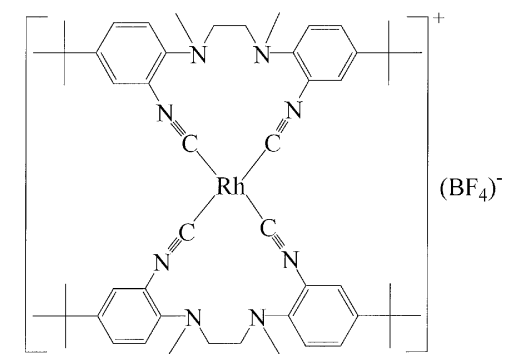

Fig. 1 Chemical structure of the title complex. 
Table 1 Crystal and experimental data

\begin{tabular}{|c|c|}
\hline Formula & $\mathrm{C}_{52} \mathrm{H}_{68} \mathrm{BF}_{4} \mathrm{~N}_{8} \mathrm{R} \cdot 0.5\left(\mathrm{C}_{6} \mathrm{H}_{14}\right) \cdot \mathrm{C}_{2} \mathrm{H}_{6} \mathrm{O}$ \\
\hline Formula weight & 1084.02 \\
\hline Temperature & $100(2) \mathrm{K}$ \\
\hline Crystal size & $0.31 \times 0.12 \times 0.12 \mathrm{~mm}$ \\
\hline Crystal color & red \\
\hline Crystal description & prismatic \\
\hline Crystal system & triclinic \\
\hline Space group & $P \overline{1}$ \\
\hline Z & 2 \\
\hline Cell dimensions & $\begin{array}{l}a=10.3165(6) \AA \\
b=15.5162(9) \AA \\
c=19.0534(11) \AA \\
\alpha=68.166(1)^{\circ} \\
\beta=78.973(1)^{\circ} \\
\gamma=89.329(1)^{\circ}\end{array}$ \\
\hline$V$ & $2773.0(3) \AA^{3}$ \\
\hline$D_{\text {calc }}$ & $1.298 \mathrm{~g} \mathrm{~cm}^{-3}$ \\
\hline Radiation & $0.71073 \AA\left(\mathrm{Mo} K_{\alpha}\right)$ \\
\hline$\mu\left(\right.$ Mo $\left.K_{\alpha}\right)$ & $0.368 \mathrm{~mm}^{-1}$ \\
\hline Monochromator & graphite \\
\hline No. of reflections used & 11313 \\
\hline No. of parameters & 699 \\
\hline $2 \theta_{\max }$ & $52.74^{\circ}$ \\
\hline$R$ & 0.0623 \\
\hline Goodness of fit & 1.051 \\
\hline$(\Delta / \sigma)_{\max }$ & 4.096 \\
\hline$(\Delta \rho)_{\max }$ & $0.949 \mathrm{e}^{-3}$ \\
\hline$(\Delta \rho)_{\min }$ & $-0.800 \mathrm{e}^{-3}$ \\
\hline Measurement & Bruker SMART CCD-1000 \\
\hline Program system & SADABS \\
\hline Structure determination & SHELXS-97 (Sheldrick, 1990) \\
\hline Refinement & SHELXL-97 (Sheldrick, 1997) \\
\hline \multicolumn{2}{|c|}{$\begin{array}{l}\text { CCDC } 269313 \text { contains the supplementary crystallographic data } \\
\text { for this paper. These data can be obtained free of charge from } \\
\text { The Cambridge Crystallographic Data Centre via } \\
\text { www.ccdc.cam.ac.uk/data_request/cif. }\end{array}$} \\
\hline
\end{tabular}

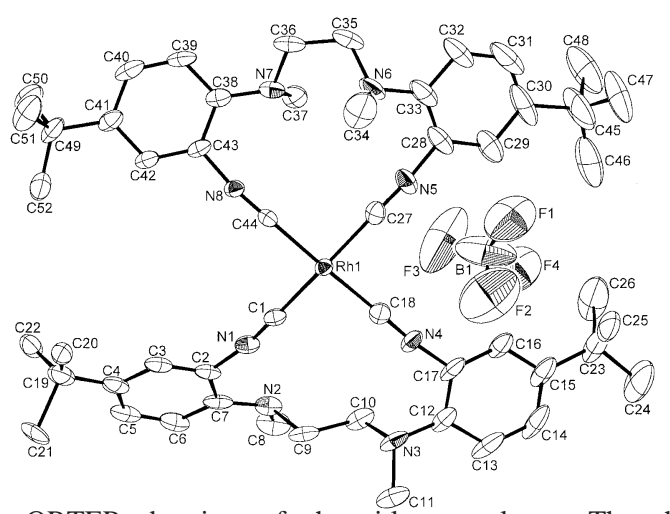

Fig. 2 ORTEP drawing of the title complex. The thermal ellipsoids are drawn at the $50 \%$ probability level. The $\mathrm{H}$ atoms are omitted for clarity.

ring structure. ${ }^{3} \mathrm{BF}_{4}{ }^{-}$exists as an anion. The $\mathrm{Rh}$ atom and four carbon atoms are almost in the same plane. The angle of $\mathrm{C}(1)-\mathrm{Rh}(1)-\mathrm{C}(27)$ is $168.39(16)^{\circ}$ and the angle of $\mathrm{C}(18)-\mathrm{Rh}(1)-\mathrm{C}(44)$ is $171.86(16)^{\circ}$. Furthermore, the angles of $\mathrm{N}(1)-\mathrm{C}(1)-\mathrm{Rh}(1), \quad \mathrm{N}(4)-\mathrm{C}(18)-\mathrm{Rh}(1), \quad \mathrm{N}(5)-\mathrm{C}(27)-\mathrm{Rh}(1)$,
Table 2 Selected bond distances $(\AA)$ and angles $\left({ }^{\circ}\right)$

\begin{tabular}{llll}
$\mathrm{C}(1)-\mathrm{N}(1)$ & $1.152(5)$ & $\mathrm{C}(27)-\mathrm{N}(5)$ & $1.153(6)$ \\
$\mathrm{C}(1)-\mathrm{Rh}(1)$ & $1.949(4)$ & $\mathrm{C}(27)-\mathrm{Rh}(1)$ & $1.976(5)$ \\
$\mathrm{C}(18)-\mathrm{N}(4)$ & $1.167(6)$ & $\mathrm{C}(44)-\mathrm{N}(8)$ & $1.165(5)$ \\
$\mathrm{C}(18)-\mathrm{Rh}(1)$ & $1.944(5)$ & $\mathrm{C}(44)-\mathrm{Rh}(1)$ & $1.959(4)$ \\
$\mathrm{C}(2)-\mathrm{N}(1)$ & $1.387(5)$ & $\mathrm{C}(28)-\mathrm{N}(5)$ & $1.393(6)$ \\
$\mathrm{C}(17)-\mathrm{N}(4)$ & $1.390(5)$ & $\mathrm{C}(43)-\mathrm{N}(8)$ & $1.396(5)$ \\
$\mathrm{C}(9)-\mathrm{C}(10)$ & $1.521(7)$ & $\mathrm{C}(35)-\mathrm{C}(36)$ & $1.523(7)$ \\
& & & \\
$\mathrm{N}(1)-\mathrm{C}(1)-\mathrm{Rh}(1)$ & $172.4(3)$ & $\mathrm{N}(5)-\mathrm{C}(27)-\mathrm{Rh}(1)$ & $172.9(4)$ \\
$\mathrm{N}(4)-\mathrm{C}(18)-\mathrm{Rh}(1)$ & $174.3(4)$ & $\mathrm{N}(8)-\mathrm{C}(44)-\mathrm{Rh}(1)$ & $174.6(3)$ \\
$\mathrm{C}(1)-\mathrm{N}(1)-\mathrm{C}(2)$ & $170.7(4)$ & $\mathrm{C}(27)-\mathrm{N}(5)-\mathrm{C}(28)$ & $174.8(5)$ \\
$\mathrm{C}(18)-\mathrm{N}(4)-\mathrm{C}(17)$ & $173.8(4)$ & $\mathrm{C}(44)-\mathrm{N}(8)-\mathrm{C}(43)$ & $172.4(4)$ \\
$\mathrm{N}(2)-\mathrm{C}(9)-\mathrm{C}(10)$ & $112.1(3)$ & $\mathrm{N}(6)-\mathrm{C}(35)-\mathrm{C}(36)$ & $111.8(4)$ \\
$\mathrm{C}(7)-\mathrm{N}(2)-\mathrm{C}(8)$ & $115.6(4)$ & $\mathrm{C}(33)-\mathrm{N}(6)-\mathrm{C}(34)$ & $115.8(5)$ \\
$\mathrm{C}(7)-\mathrm{N}(2)-\mathrm{C}(9)$ & $114.1(3)$ & $\mathrm{C}(33)-\mathrm{N}(6)-\mathrm{C}(35)$ & $114.9(4)$ \\
$\mathrm{C}(8)-\mathrm{N}(2)-\mathrm{C}(9)$ & $111.8(4)$ & $\mathrm{C}(34)-\mathrm{N}(6)-\mathrm{C}(35)$ & $116.2(5)$ \\
$\mathrm{N}(3)-\mathrm{C}(10)-\mathrm{C}(9)$ & $111.5(3)$ & $\mathrm{N}(7)-\mathrm{C}(36)-\mathrm{C}(35)$ & $113.1(4)$ \\
$\mathrm{C}(12)-\mathrm{N}(3)-\mathrm{C}(11)$ & $114.2(4)$ & $\mathrm{C}(38)-\mathrm{N}(7)-\mathrm{C}(37)$ & $113.4(4)$ \\
$\mathrm{C}(12)-\mathrm{N}(3)-\mathrm{C}(10)$ & $112.0(3)$ & $\mathrm{C}(38)-\mathrm{N}(7)-\mathrm{C}(36)$ & $114.7(4)$ \\
$\mathrm{C}(11)-\mathrm{N}(3)-\mathrm{C}(10)$ & $112.4(4)$ & $\mathrm{C}(37)-\mathrm{N}(7)-\mathrm{C}(36)$ & $115.0(4)$ \\
$\mathrm{C}(18)-\mathrm{Rh}(1)-\mathrm{C}(1)$ & $89.05(18)$ & $\mathrm{C}(44)-\mathrm{Rh}(1)-\mathrm{C}(27)$ & $90.59(17)$ \\
$\mathrm{C}(18)-\mathrm{Rh}(1)-\mathrm{C}(44)$ & $171.86(16)$ & $\mathrm{C}(1)-\mathrm{Rh}(1)-\mathrm{C}(27)$ & $168.39(16)$ \\
$\mathrm{C}(1)-\mathrm{Rh}(1)-\mathrm{C}(44)$ & $89.70(16)$ & $\mathrm{C}(18)-\mathrm{Rh}(1)-\mathrm{C}(27)$ & $89.03(18)$ \\
\hline
\end{tabular}

$\mathrm{N}(8)-\mathrm{C}(44)-\mathrm{Rh}(1)$ are $172.4(3)^{\circ}, 174.3(4)^{\circ}, 172.9(4)^{\circ}$, and $174.6(3)^{\circ}$, respectively. This also determines the square-planar structure of the complex. The mean bond length between the $\mathrm{Rh}$ atom and carbon atoms is $1.957 \AA$. The mean bond length between the isocyano groups and the phenyl groups is $1.392 \AA$. Two of them are longer than the mean bond length of $\mathrm{C} \equiv \mathrm{N}$, which is $1.159 \AA$. Two carbon atoms of bridging groups are at two sides of the square-planar structure. Though the angles of $\mathrm{N}(2)-\mathrm{C}(9)-\mathrm{C}(10)$ and $\mathrm{N}(3)-\mathrm{C}(10)-\mathrm{C}(9)$ (112.1(3) ${ }^{\circ}$ and 111.5(3) ${ }^{\circ}$, respectively) are similar to those of $\mathrm{N}(6)-\mathrm{C}(35)-\mathrm{C}(36)$ and $\mathrm{N}(7)-\mathrm{C}(36)-\mathrm{C}(35) \quad\left(111.8(4)^{\circ} \quad 113.1(4)^{\circ}\right.$, respectively), two bridging groups in two ligands show different configurations. One of them is a boat form $(\mathrm{N}(6)-\mathrm{C}(35)-\mathrm{C}(36)-\mathrm{N}(7))$, and the other is a chair form $(\mathrm{N}(2)-\mathrm{C}(9)-\mathrm{C}(10)-\mathrm{N}(3))$. This disordered structure may be due to the interaction among the complex cation, the $\mathrm{BF}_{4}^{-}$anion and the solvents. Furthermore, the maximum shift in the last refinement $\left((\Delta / \sigma)_{\max }\right)$ did not converge, though the least-squares technique was used (Table 1). This may be due to the disordered structure.

\section{Acknowledgements}

We are grateful to the Center for Instrumental Analysis, Kyushu Institute of Technology, for elemental analyses, mass spectra, and ${ }^{1} \mathrm{H}$ NMR spectra, and Prof. H. Hisaeda in Kyushu University for crystal data collection.

\section{References}

1. R. J. Angelici, M. H. Quick, G. A. Kraus, and D. T. Plummer, Inorg. Chem., 1982, 21, 2178.

2. D. T. Plummer, B. A. Karcher, R. A. Jacobson, and R. J. Angelici, J. Organomet. Chem., 1984, 260, 347.

3. K. Sakata, K. Urabe, M. Hashimoto, T. Yanagi, A. Tsuge, and R. J. Angelici, Synth. React. Inorg. Met.-Org. Chem., $\mathbf{2 0 0 3}, 33,11$. 